\title{
Ecological Corridor as a Factor Determining the Structure and Organization of a Bank Vole Population
}

\author{
Jakub SZACKI ${ }^{1}$
}

Szacki J., 1987: Ecological corridor as a factor determining the structure and organization of a bank vole population. Acta theriol., 32, 3: $31-44$ [With 4 Tables and 4 Figs.]

This study analyses the effect of an ecological corridor joining two biotopes on the frequency of movements of the bank vole, Clethrionomys glareolus (Schreber, 1780) and the yellow-necked mouse, Apodemus flavicollis (Melchior, 1834) between these biotopes. Also consequences of the presence of this corridor for populations of these rodents inhabiting habitat islands were examined. The ecological corridor had a marked effect on the frequency of movements of C. glareolus, whereas movements of A. flavicollis were not affected. In all the seasons, the density of the bank vole population was higher in the isolated area than in the semi-isolated area connected with a forest complex by the ecological corridor. No such differences were found for the yellow-necked mouse. The isolated population of the bank vole, as compared with semi-isolated one, had a longer mean time of the occurrence of individuals in it, a higher proportion of juveniles in the group of new-marked individuals, smaller sizes of individual home ranges, smaller shifts of home ranges from season to season and a higher overlap of home ranges. The difference between trappability of individuals marked in a given season and trappability of individuals marked in previous seasons was significantly higher in the isolated than in the semi-isolated population.

[Dept. of Zoology and Ecology, University of Warsaw, Krakowskie Przedmieście 26/28, 00-927/1 Warsaw, Poland]

\section{INTRODUCTION}

Independently of differences in views on the nature of regulatory processes in rodent populations, all the authors agree that migrations are important for their functioning (e.g. Gadgil, 1971; Lidicker, 1975; Krebs, 1978; Petrusewicz, 1983a). Thus it can be assumed that reduction of migration by at least partial isolation of a population should yield important consequences. Semi-isolated populations include those inhabiting the so-called habitat islands, that is, patches of a suitable habitat surrounded by other, less suitable habitats (MacArthur, 1972; Diamond

1 Present address: Inst. of Physical Planning and Municipal Economy, L. Krzywickiego 9, 02-078 Warsaw, Poland. 
\& May, 1976; Gliwicz, 1980). Attempts are made to apply the biogeographic theory of MacArthur and Wilson (1967) to such habitat islands, and to use it as a basis for planning nature reserves (Simberloff \& Abele, 1982; Kindlmann, 1983; Diamond, 1984). The understanding of the mechanisms of population isolation on habitat islands and the possibilities of its reduction is not only of theoretical importance. The isolation of the populations occupying habitat islands can be reduced by the socalled ecological corridors connecting different habitat patches. Their important role was emphasized by many authors (Wilson \& Willis, 1975; Gliwicz, 1980; Forman, 1983, and others) but studies on this subject are rare.

The objective of this study has been to observe whether an ecological corridor connecting two biotopes enhances movements of the bank vole and yellow-necked mouse between these two biotopes. The effect of the corridor has been estimated by comparing the bank vole population occupying a habitat island with another population occupying a similar area but connected with a large forest complex by an ecological corridor.

\section{STUDY AREA, METHODS, AND MATERIAL}

The study was conducted near Mikolajki, Mazuria, north-eastern Poland $\left(53^{\circ} 48^{\prime} \mathrm{N}\right.$, $\left.21^{\circ} 34^{\prime} \mathrm{E}\right)$. The study area consisted of an isolated woodlot, a semi-isolated woodlot, and an ecological corridor connecting the semi-isolated woodlot with a large forest complex. The isolated area ( $0.9 \mathrm{ha})$ and the semi-isolated area (2.5 ha) supported forest communities dominated by pine, with undergrowth of the class QuercoFagetea and herb layer of the classes Querco-Fagetea and Molinio-Arrhenatheretea. They were surrounded by moist meadows (class Molinio-Arrhenatheretea). The ecological corridor was a belt of an alder thicket (fragments of an alder-ash wood, Circaeo-Alnetum) with a sparse herblayer predominated by plants of the classes Molinio-Arrhenatheretea and Artemisietea. The distance between the isolated and semi-isolated areas was the same as between the semi-isolated area and the forest complex and it amounted to about $60 \mathrm{~m}$.

The CMR method was used. Live traps were set on a grid $15 \mathrm{~m}$ apart. The grid covered the whole area of the two forest patches, the belt of the alder thicket and the edge of the forest complex (Fig. 1). The traps were baited with oats. The animals caught were marked by toe clipping.

Sexual activity was assessed by external examination of sexual organs. Males with clearly augmented testes and females with open vaginas were considered as active.

The study was carried out in 1981 and 1982 in four 10-day series of trapping: in spring (the second half of April), early summer (the second half of June), late summer (the second half of August), and in autumn (the second half of October).

Turn-over of individuals in the population was calculated after Petrusewicz (1983 b). Following Taitt (1981), bank voles weighing $14 \mathrm{~g}$ or less were considered as young individuals. They were not sexually active over the study period. Home range sizes were calculated using an elliptic model (Mazurkiewicz, 1969). The 
overlap of home ranges was calculated as a ratio of the product of the mean home range and the number of individuals caught at least five times to the respective habitat size.

Statistical significance of differences between means was examined by Student's t-test, equality of variances by Fischer's F-test, and differences in proportions by the test of difference between two fractions. Significance of differences between mean numbers of captures was estimated by the Kolgomorov-Smirnov nonparametric test, since the distribution of the number of captures was not normal.

The material consisted of 971 small rodents captured 5180 times. They represented nine species: C. glareolus, A. flavicollis, Microtus agrestis (Linnaeus, 1761), Microtus oeconomus (Pallas, 1776), Microtus arvalis (Pallas, 1779), Apodemus agrarius (Pallas, 1771), Micromys minutus (Pallas, 1771), Mus musculus Linnaeus, 1758 and Sicista betulina (Pallas, 1778). As most of the species occurred in low numbers, only the bank vole and the yellow-necked mouse were analyzed in detail.

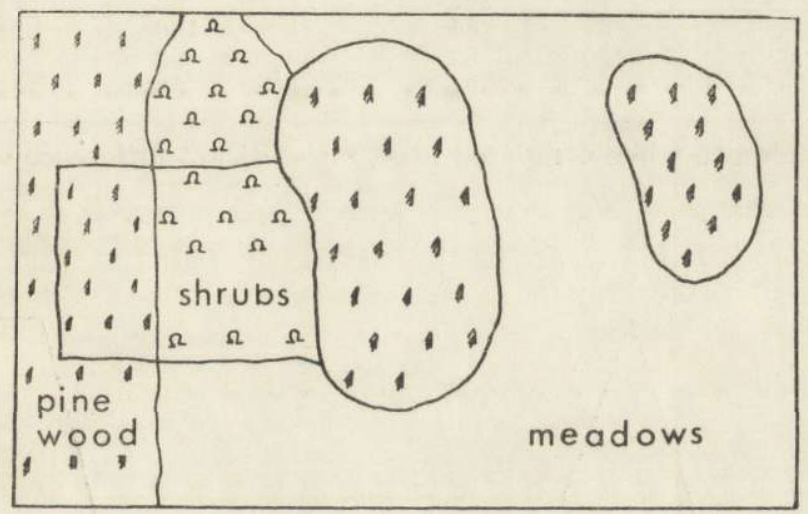

Fig. 1. Study area. Traps were set on the whole area of isolated and semi-isolated woodlots, in the belt of alder thicket (shrubs) and at the border of the forest complex.

\section{RESULTS}

\subsection{Characteristics of Small Rodents Occurring in the Alder Thicket of the Ecological Corridor}

In this biotope, the community of small rodents was characterized by a large number of species. It consisted of all the nine species recorded from the entire study area over the 2-year study period. Most of these species occurred sporadically and only in some seasons, and during individual series of trapping they were also caught in adjacent biotopes, thus these were individuals living at the edge of two habitats rather than associated with the belt of alder thicket. The only species permanently associated with this habitat was $M$. oeconomus.

In the alder thicket, the proportion of C. glareolus in the community 
Table 1

Proportions of bank voles ( $f$ ) in small rodents communties of different study areas: isolated, semi-isolated and thicket $(\%) ; n$ is the number of individuals in the community.

\begin{tabular}{|c|c|c|c|c|c|c|}
\hline \multirow{3}{*}{ Season } & \multicolumn{6}{|c|}{ Area } \\
\hline & \multicolumn{2}{|c|}{ A. Semi-isolated } & \multicolumn{2}{|c|}{ B. Isolated } & \multicolumn{2}{|c|}{ Thicket } \\
\hline & $n$ & $f$ & $n$ & f & $n$ & $f$ \\
\hline 1981 & & & & • & & \\
\hline Spring & 13 & 77 & 6 & 100 & 1 & 0 \\
\hline Early summer & 55 & 60 & 32 & 81 & 29 & $31^{\mathrm{b}}$ \\
\hline Late summer & 124 & 49 & 62 & 82 & 72 & $24^{\mathrm{a}, \mathrm{b}}$ \\
\hline Autumn & 103 & 34 & 45 & 67 & 77 & $16^{\mathrm{a}, \mathrm{b}}$ \\
\hline \multicolumn{7}{|l|}{1982} \\
\hline Spring & 14 & 100 & 11 & 82 & 21 & $14^{a, b}$ \\
\hline Early summer & 34 & 85 & 21 & 100 & 24 & $62^{\mathrm{a}, \mathrm{b}}$ \\
\hline Late summer & 100 & 88 & 52 & 98 & 45 & $67^{\mathrm{a}, \mathrm{b}}$ \\
\hline Autumn & 98 & 81 & 51 & 98 & 41 & $66^{\mathrm{a}, \mathrm{b}}$ \\
\hline
\end{tabular}

a significant difference when compared to A, b significant difference when compared to $\mathrm{B}(p<0.05)$

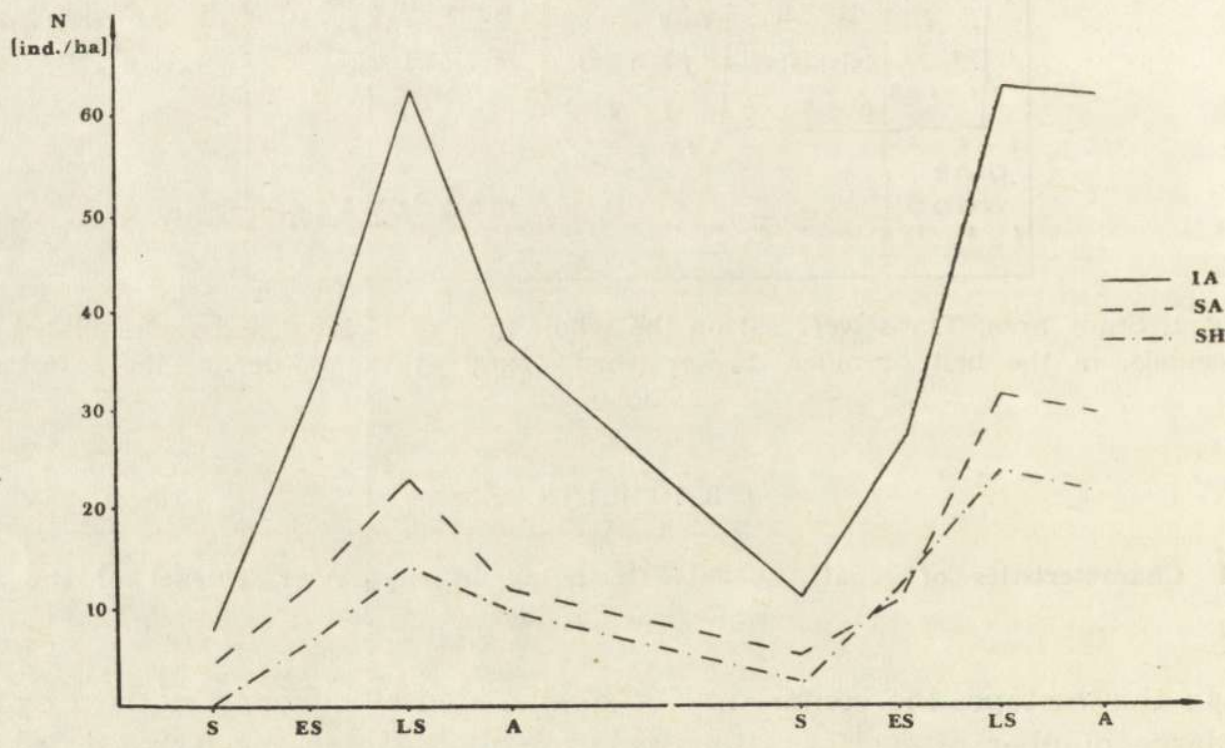

Fig. 2. Changes in the density of bank voles in the isolated area (IA), semi-isolated area (SA), and in the thicket (SH). S - spring, ES - early summer, LS - late summer, A - autumn.

of small mammals was lower than in the other areas (Table 1). Also the density of this species was lower in this habitat (Fig. 2). Most of the bank voles caught in the alder thicket only visited this habitat, and they 
were also caught in the adjacent forest. Few individuals caught only in the thicket were noted there no longer than over one season. Only on three occasions such individuals were caught in subsequent trapping series on other study plots.

The majority of individuals caught only in the alder thicket were "new" i.e. they had not been caught in previous trapping series. Their numbers depended on the population density - in spring they were absent, and their highest numbers were recorded in late summer and autumn.

\subsection{Intensity of Movements}

In 8 trapping series, 50 cases of movements of 31 bank voles were noted between the semi-isolated area and the forest complex. The number of these movements was not proportional to the population density. A highest number of 26 movement occurred in early summer, when the population density was low. Less such movements took place in periods of a high population density, that is, in late summer (14) and autumn (8). In spring only two cases of movements between the forest complex and the semi-isolated area were recorded ${ }^{2}$. No movements of bank voles were recorded from the isolated area into other study areas. Occasionally, such movements were recorded for yellow necked mice, though the density of the population of this species was much lower and, consequently, the probability of recording such a movement was also lower.

\subsection{Comparison of C. glareolus Populations on the Isolated and Semi-isolated Areas}

\subsubsection{Changes in Numbers, Turn-over Rate of Individuals}

Changes in numbers of the bank vole populations were similar on the areas compared. In both cases densities reached a peak in late summer, and they were lowest in spring. In all the seasons, the isolated population had higher densities. The largest differences were noted in the periods of annual peaks (Fig. 2). In the first study year, the population of A. flavicollis was sufficiently large to compare its density on the isolated and semi-isolated areas. No differences were recorded (Fig. 3).

Individual turn-over in the bank vole population, calculated for the period from spring 1981 to autumn 1982, was significantly lower $(p<0.05)$ for the isolated population ( 0.5 versus 5.9 ). Thus, the mean time of the presence of an individual in the area, calculated from population turn-

2 The number of movements in particular seasons is given for the two succesive study years jointly. 
over, was longer for the isolated than semi-isolated population (115 versus 97 days).

In the late summer of 1981 and in the autumn of 1982, the proportion of juvenile individuals in the group of newly marked voles, thus recruited to the population, was higher in the isolated than semi-isolated population (Table 2 ).

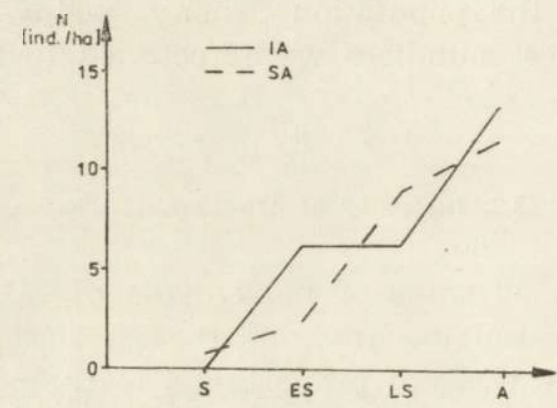

Fig. 3. Changes in the density of yellow-necked mice in the isolated (IA) and semi-isolated (SA) areas.

Table 2

Proportions of juveniles $(j)$ in the group of "new" (not marked in previous seasons) individuals in the isolated and semi-isolated populations of bank voles $(\%) ; n$ is the number of new individuals.

\begin{tabular}{|c|c|c|c|c|}
\hline \multirow{3}{*}{ Season } & \multicolumn{4}{|c|}{ Population } \\
\hline & \multicolumn{2}{|c|}{ Semi-isolated } & \multicolumn{2}{|c|}{ Isolated } \\
\hline & $n$ & $j$ & $n$ & $j$ \\
\hline \multicolumn{5}{|l|}{1981} \\
\hline Spring & 10 & 0 & 6 & 0 \\
\hline Early summer & 24 & .10 & 19 & 11 \\
\hline Late summer & 47 & 33 & 37 & $51^{1}$ \\
\hline Autumn & 19 & 6 & 9 & 28 \\
\hline \multicolumn{5}{|l|}{1982} \\
\hline Spring & 7 & 0 & 3 & 0 \\
\hline Early summer & 24 & 9 & 14 & 13 \\
\hline Late summer & 78 & 37 & 42 & 44 \\
\hline Autumn & 30 & 11 & 16 & $36^{1}$ \\
\hline
\end{tabular}

${ }^{1} p<0.05$

3.3.2. Sex Ratio and Sexual Activity

The proportion of males in the two areas ranged from 40 to $70 \%$. The sex ratio did not significantly deviate from $1: 1$. No significant differences between the two populations were found in male to female ratio. 
The proportion of sexually active males was significantly higher $(p<0.05)$ in the isolated population as compared with the semi-isolated one only in the early summer of 1982 ( $85 \%$ and $33 \%$, respectively). In the same season, the proportion of sexually active females was significantly lower $(p<0.05)$ in the isolated than semi-isolated population $(37 \%$ and $67 \%$, respectively). In the other seasons, no differences between the two populations were noted in the proportion of sexually active females.

\subsubsection{Trappability}

No statistically significant differences were noted in the mean number of captures per individual between the isolated and semi-isclated populatio.s.
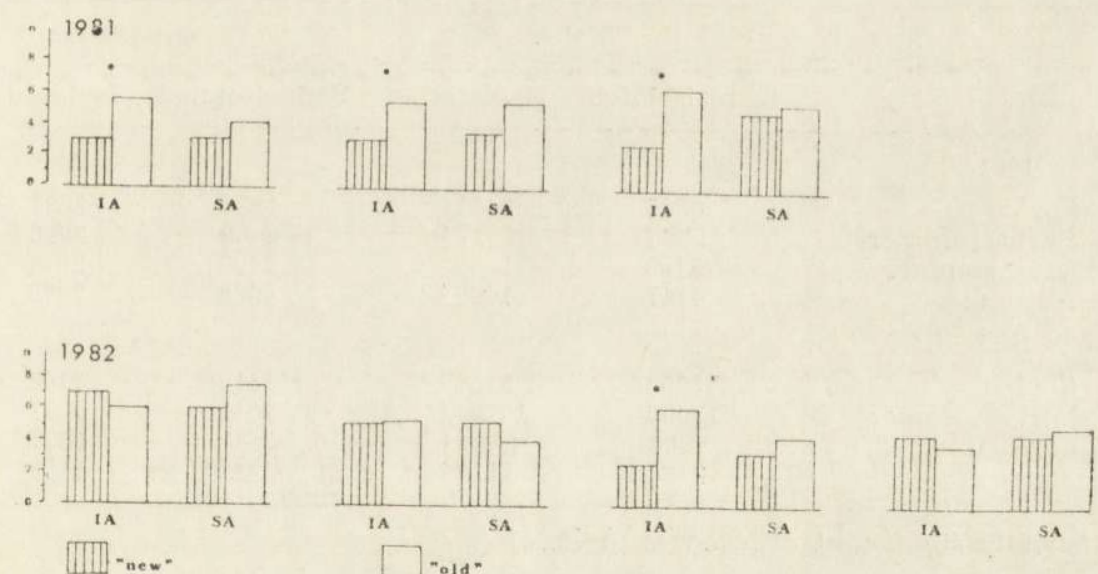

Fig. 4. Mean numbers of captures of "new" and "old" bank voles captured in the isolated (IA) and semi-isolated (SA) areas. "New" individuals were caught for the first time in a given trapping season and "old" had been caught in previous seasons. Asterisks denote statistically significant differences $(p<0.05)$.

For each trapping series the trappability (i.e. the number of captures per individual during the trapping series) of "new", individuals that is, marked in a given season, was compared to the trappability of indivicuals marked in previous seasons on the two areas. In the semiisolated area, no significant differences were found between the two groups $(0>0.1)$. In the isolated area, however, the mean number of cantures of individuals marked in previous seasons was significantly higher than the mean number of captures of "new" individuals $(p<0.05)$ in three seasons of the first year and in the late summer of the second year 'Fig. 4). 


\subsubsection{Spatial Organization}

In the two areas, home ranges of males were larger than those of females in all the seasons, except for the autumn of 1981 (Table 3).

The size of home ranges of both males and females in the two areas varied within a year. Males held largest home ranges in spring and early summer, and smallest in autumn (Table 3). The home ranges of females were less variable in size from season to season than those of males. No significant correlation between the home range size and population numbers were recorded for the two areas.

Table 3

Sizes of home ranges of males and females in the isolated and semi-isolated populations of bank voles $\left(\mathrm{m}^{2}\right)$.

\begin{tabular}{|c|c|c|c|c|}
\hline \multirow{2}{*}{ Season } & \multicolumn{2}{|c|}{ Males } & \multicolumn{2}{|c|}{ Females } \\
\hline & Semi-isolated & Isolated & Semi-isolated & Isolated \\
\hline \multicolumn{5}{|l|}{1981} \\
\hline $\begin{array}{l}\text { Spring } \\
\text { Early summer } \\
\text { Late summer } \\
\text { Autumn }\end{array}$ & $\begin{array}{r}6366 \\
15886 \\
5198 \\
4147\end{array}$ & $\begin{array}{l}3401 \\
8527^{1} \\
2862 \\
1460^{1}\end{array}$ & $\begin{array}{l}1986 \\
8469 \\
2103 \\
4322\end{array}$ & $\begin{array}{l}2631 \\
2920^{1} \\
2044 \\
2278\end{array}$ \\
\hline \multicolumn{5}{|l|}{1982} \\
\hline $\begin{array}{l}\text { Spring } \\
\text { Early summer } \\
\text { Late summer } \\
\text { Autumn }\end{array}$ & $\begin{array}{c}13958 \\
12090 \\
6308 \\
3154\end{array}$ & $\begin{array}{r}3154^{1} \\
10104^{1} \\
3154^{1} \\
1518^{1}\end{array}$ & $\begin{array}{l}1518 \\
2044 \\
5631 \\
2219\end{array}$ & $\begin{array}{l}1168 \\
3271 \\
1577^{1} \\
1168\end{array}$ \\
\hline
\end{tabular}

1 statistically significant differences $(p<0.05)$

Table 4

Overlap of individual home ranges in the isolated and semi-isolated populations of bank voles.

\begin{tabular}{llc}
\hline \multirow{2}{*}{ Season } & \multicolumn{2}{c}{ Population } \\
\cline { 2 - 3 } & Semi-isolated & Isolated \\
\hline 1981 & & \\
Spring & 0.8 & 1.9 \\
Early summer & 4.0 & 6.4 \\
Late summer & 3.1 & 4.3 \\
Autumn & 2.4 & \\
$\quad 1982$ & & 1.6 \\
Spring & 2.9 & 7.4 \\
Early summer & 2.3 & 5.5 \\
Late summer & 4.7 & 3.6 \\
Autumn & 2.7 & \\
\hline
\end{tabular}


In most of the seasons, home ranges of males were significantly larger $(p<0.05)$ in the semi-isolated than isolated area. For females this relationship was less clear (Table 3).

The overlap of home ranges was larger on the isolated than semiisolated area. The only exception was the spring of the second study year (Table 4).

Shifts of home ranges for both males and females were larger in the semi-isolated area. Mean values for the periods between succesive trapping series over the two-year study period were $15.3 \mathrm{~m}$ for voles in the isolated area and $38.1 \mathrm{~m}$ for voles in the semi-isolated area. The difference is statistically significant $(p<0.01)$.

\section{DISCUSSION}

Neadows surrounding the isolated area represent a barrier for bank voles. No one individual of this species crossed them during the eight trapping series. The belt of alder thicket connecting the semi-isolated area with the forest complex markedly reduced the isolating effect of meadows. The evidence of this was provided by records of movements of bank voles between the semi-isolated area and the forest.

Bank voles sparsely occurring in the alder thicket in the periods of high population densities were young or migrating individuals. It is assumed that these are "poorer" individuals, representing a population surplus which is forced to marginal habitats when population densities are high. A high disappearance rate of individuals from the alder thicket implies that their mortality was high or that they migrated rapidly. Thus, bank voles are not permanently associated with this habitat. But being a marginal habitat, the belt of alder thicket can serve as an ecological corridor for bank voles, faciliating their movements. This is also indicated by the fact that the highest number of movements through this corridor occurred in the period of low population density, thus in the period of disperal of dominant individuals (Lidicker, 1975). An occasional presence in the alder thicket of other species not permanently associated with this habitat shows that it can be used as an ecological corridor not only by bank voles.

If the belt of alder thicket really performed the role of an ecological corridor reducing the isolation of small mammals populations, then the population inhabiting the isolated area should differ from that occurring in the semi-isolated area.

The density of the isolated population was higher than that of the semi-isolated population. Higher densities than in open populations were noted on islands (e.g. Mazurkiewicz, 1972; Sullivan, 1977; Burns, 1981), in experimental enclosures (Petrusewicz, 1963; Krebs et al., 1969), and 
on habitat islands (Smith \& Vrieze, 1979; Wegner \& Merriam, 1979). Some authors, however found lower densities in populations occurring on habitat islands than in open populations (Stickel \& Warbach, 1960; Windberg \& Keith, 1978; Gottfried, 1979, 1982). It seems that this may be an effect of only partial isolation of a given population. For some species the habitat surrounding a habitat may represent a much more effective barrier than for other species. In this study, the meadows surrounding the forest patch proved to be a more effective barrier for bank voles than for yellow-necked mice and, at the same time, differences in the population density between the isolated and semi-isolated areas were much greater for the bank vole than for the yellow-necked mouse. Similarly, Yahner $(1982,1983)$ has found that the species typical of forests reached higher densities in shelterbelts surrounded by farmland than in a nearby forest, whereas the density of the species less associated with forests was lower in shelterbelts. Thus, the isolation of habitat islands is relative - it depends on the biology of particular species. As Kozakiewicz (1981) has noted, emigration from a semi-isolated bank vole population is always possible, thus reduction in numbers is always possible in this way. Immigration, however, is little probable, since the chance that a bank vole will find a habitat island while crossing the unsuitable habitat is small. In such a population emigration will considerably outweigh immigration, and, as a result its size will be low. In an isolated population also emigration is reduced - an alien habitat surrounding the island accounts for the fact that a stronger intrapopulation pressure is needed to give rise to emigration, and, consequently, the density of such a population will be higher.

The isolated area was much smaller than the semi-isolated one, and laboratory experiments have shown that population density is inversely related to the size of the area (Petrusewicz \& Uchmański 1980). However, no such pattern was noted on habitat islands. Gottfried (1982), who studied populations of small mammals on habitat islands of a size of several hundred square meters, has found that population densities increased with island size. Absence of correlation between the size of a habitat island and population density or even a positive correlation between these variables have been recorded for different animal species and various size classes of habitat islands (Yahner, 1982, 1983; Lynch \& Whigham, 1984; Henderson et al., 1985, and others). Also the present comparison of the population densities of bank voles and yellow-necked mice from the isolated and semi-isolated areas suggests that the population density on a habitat island depends on the degree of isolation rather than on the island size. And so the density of the bank vole population was clearly higher on the isolated than on the semi-isolated 
area, whereas the density of the yellow-necked mouse population, for which meadows surrounding the isolated area did not prevent movements, was alike in the two situations.

The isolated population of the bank vole was less migrating than the semi-isolated population. In addition to direct data on the mobility of individuals in the populations compared, this is also shown by a lower value of individual turn-over in the isolated population, and a higher proportion of juveniles recruited to the population. Presumably, this could give rise to differences in the spatial organization and trappability of individuals in the populations compared. Individual home ranges were smaller in the isolated population than in the semi-isolated one. These differences, combined with a lack of correlation between the population density and the home range size on the two areas provide evidence that not only density per se accounted for the reduction in home range sizes: in the isolated population. This reduction could have been an effect of a lower aggresiveness of individuals in the isolated population. Such a possibility is confirmed by a higher overlap of individual home ranges in the isolated than in the semi-isolated population. Reduction of home range sizes may also be an adaptation reducing the number of encounters among individuals. These two possibilities are not mutually exclusive, and both imply that the isolated population had a specific social organization.

The social structure of the population is also reflected by the trappability of individual animals. Higher trappability is characteristic of dominant individuals, lower of migrants and juveniles (Petrusewicz \& Andrzejewski, 1962). Although no significant differences were found in the mean number of captures per individual between the isolated and semi-isolated populations, the distinctiveness of the social structure of the isolated population can be inferred from a comparison of the number of captures per newly marked individual and per individual marked earlier (i.e. in previous seasons) in either population. Newly captured individuals were immigrants or juveniles. Recaptured individuals (marked in previous seasons) were adults, occupying a given area at least from the preceding trapping series. Thus, typically, these were dominant individuals. A greater difference in trappability between these two groups. of individuals in the isolated population signifies that the social organization of this population is "more distinct" (Gliwicz, 1980) as compared with the semi-isolated population.

A higher persistence of the spatial organization of the isolated population can be inferred from a comparison of the shifts of activity centres, that is, geometric centres of home ranges, from season to season in the two populations. Smaller shifts in the isolated populations are 
indicative of a stronger attachment of individuals in this population to a given place, presumably as a result of stronger interactions among them.

In the second study year, when the starting density of the population was higher, the proportion of sexually active females was lower in the isolated population as compared with the semi-isolated population. These data show that in the situation when emigration is reduced, the limitation of reproduction can be an alternative way of reducing population numbers.

The differences recorded between the isolated and semi-isolated populations indicate that the ecological corridor had an important role in the functioning of the bank vole population.

Acknowledgements: I wish to thank Prof. K. Dobrowolski for critical comments during my work on this paper, Prof. Z. Podbielkowski and Ass. Prof. H. Tomaszewicz for characteristics of plant communities, and $\mathrm{Dr}$ S. Nowotny for statistical calculations.

\section{REFERENCES}

1. Burns G. R., 1981: Population dynamics of island populations of subarctic Clethrionomys rutilus. Can. J. Zool., 59: 2115-2122.

2. Diamond J. M., 1984: Distributions of New Zealand birds on real and virtual islands. New Zealand J. Ecol., 7: 37-55.

3. Diamond J. M. \& May R. M., 1976: Island biogeography and the design of natural reserves. [In: "Theoretical ecology: principles and applications", R. M. May, ed.]. Blackwell Scientific Publications: 163-186. Oxford, London, Edinburg, Melbourne.

4. Forman R. T. T., 1983: Corridors in a landscape: their ecological structure and function. Ekologia (CSSR), 2: 375-387.

5. Gadgil M., 1971: Dispersal: population consequences and evolution. Ecology, 52: $253-261$.

6. Gliwicz J., 1980: Island populations of rodents: their organization and functioning. Biol. Rev., 55: 109-138.

7. Gottfried B. M., 1979: Small mammals populations in woodlot islands. Am. Midl. Nat., 102: 105-112.

8. Gottfried B. M., 1982: A seasonal analysis of small mammals populations on woodlot islands. Can. J. Zool. 60: 1660-1664.

9. Henderson M. T., Merriam G. \& Wegner J., 1985: Patchy environments and species survival: chipmunks in an agricultural mosaic. Biol. Conserv., 31: 95-105.

10. Kindlmann P., 1983: Do archipelagos preserve fewer species than one island of the same area? Oecologia, 59: 141-144.

11. Kozakiewicz ML, 1981: Rola izolacji siedliska w kształtowaniu struktury i dynamiki populacji nornicy rudej. Ph. D. thesis, University of Warsaw, $1-50$.

12. Krebs C. J., 1978: A review of the Chitty hypothesis of population regulation. Can. J. Zool., 56: 2463-2480.

13. Krebs C. J., Keller B. L. \& Tamarin R. H., 1969: Microtus population biology: demographic changes in fluctuating population of Microtus ochrogaster and 
Microtus pennsylvanicus in southern Indiana. Ecology, 50: 587-607.

14. Lidicker W. Z. Jr, 1975: The role of dispersal in the demography of small mammals. [In: "Small mammals: their productivity and population dynamics" F. B. Golley, K. Petrusewicz \& L. Ryszkowski, eds.]. Cambridge University Press: 103-128. Cambridge.

15. Lynch J. F. \& Whigham D. F., 1984: Effects of forest fragmentation on breeding bird communities in Maryland, U.S.A. Biol. Conserv., 28: 287-324.

16. MacArthur R. H., 1972: Geographical ecology: patterns in the distribution of species. Harper \& Row, New York, Evanston, San Francisco, London. 1-269.

17. MacArthur R. H. \& Wilson E. O., 1967: The theory of island biogeography. Princeton University Press, Princeton, New Jersey. 1-203.

18. Mazurkiewicz M., 1969: Elliptical modification of the home range pattern. Bull. Acad. Pol. Sci. II, 17: 427-431.

19. Mazurkiewicz M., 1972: Density and weight structure of populations of bank voles in open and enclosed areas. Acta theriol., 34: 455-465.

20. Petrusewicz K., 1963: General remarks on the productivity of confined populations. Ekol. Pol. A, 11: 617-624.

21. Petrusewicz K., 1983a: Residents and migrants in the population. [In: "Ecology of the bank vole", K. Petrusewicz, ed.]. Acta theriol., 28, suppl. 1: 128-133.

22. Petrusewicz K., 1983b: Numbers and the number of discrete individuals, turn-over. [In: "Ecology of the bank vole", K. Petrusewicz, ed.]. Acta theriol., 28: suppl. 1: 89-93.

23. Petrusewicz K. \& Andrzejewski R., 1962: Natural history of free living population of house mouse (Mus musculus L.) with particular reference to groupings within population. Ekol. Pol. A, 10: 85-122.

24. Petrusewicz K. \& Uchmański J., 1980: Density of confined and open populations: a model study. Bull. Acad. Pol. Sci. II, 28: 49-58.

25. Simberloff D. \& Abele G. L., 1982: Refuge design and island biogeographic theory: effects of fragmentation. Am. Nat, 120: 41-50.

26. Smith A. T. \& Vrieze J. M., 1979: Population structure of everglades rodents: responces to a patchy environment. J. Mamm., 60: 778-794.

27. Stickel L. F. \& Warbach O., 1960: Small mammals populations of a Maryland woodlot 1949-1954. Ecology, 41: 269-286.

28. Sullivan T. P., 1977: Demography and dispersal in island and mainland populations of the deermouse Peromyscus maniculatus. Ecology, 58: 964-978.

29. Taitt M., 1981: The effect of extra food on small rodent populations: I. Deermice (Peromyscus maniculatus). J. Anim. Ecol., 50: 111-124.

30. Wegner J. F. \& Merriam G., 1979: Movements by birds and small mammals between wood and adjoining farmland habitats. J. Appl. Ecol., 16: 349-357.

31. Wilson E. O. \& Willis E. O., 1975: Applied biogeography. [In: "Ecology and evolution of communities", M. L. Cody \& J. M. Diamond, eds.]). Harvard University Press: 522-534. Cambridge, Mass and London.

32. Windberg L. \& Keith L. B., 1978: Snowshoe hare populations in woodlot habitat. Can. J. Zool., 56: 1071-1080.

33. Yahner R. H., 1982: Microhabitat use by small mammals in farmstead shelterbelts. J. Mamm., 63: 440-445.

34. Yahner R. H., 1983: Small mammals in farmstead shelterbelts: habitat correlates of seasonal abundance and community structure. J. Wildl. Manage., 47: $74-84$.

Received, September 27, 1985. Accepted, January 10, 1986. 
Jakub SZACKI

KORYTARZ EKOLOGICZNY JAKO CZYNNIK KSZTAETUJACY STRUKTURE
I ORGANIZACJE POPULACJI NORNICY RUDEJ

Streszczenie

W trakcie dwóch kolejnych lat badano wplyw korytarza ekologicznego, będącego połączeniem między dwoma biotopami (Ryc. 1) na ruchliwość nornicy rudej i myszy leśnej. Badano również konsekwencje istnienia takiego korytarza ekologicznego porównując populację nornicy wyspy środowiskowej z populacją nornicy podobnej powierzchni, ale połączonej korytarzem ekologicznym z dużym kompleksem lasu. W badaniach stosowano metodę połowów żywołownych.

Pas zarośli olszowych stanowiący połączenie między powierzchnią izolowaną a kompleksem lasu (korytarz ekologiczny) był dla nornicy środowiskiem marginalnym (Ryc. 2, Tabela 1). Odnotowano 50 przypadków wędrówek nornicy przez korytarz ekologiczny. Równocześnie stwierdzono, że nornice nie wędrują między powierzchnią izolowaną częściowo a izolowaną. Odnotowano natomiast sporadyczne przypadki takich wędrówek myszy leśnej. Porównanie populacji nornicy powierzchni izolowanej częściowo oraz izolowanej wykazało istnienie szeregu różnic. Zagęszczenie populacji nornicy było we wszystkich sezonach wyższe na powierzchni izolowanej (Ryc. 2). Dla populacji myszy leśnej, gatunku, dla którego łąki otaczające powierzchnię izolowaną nie stanowiły przeszkody w wędrówkach, stwierdzono brak takich różnic (Ryc. 3). W izolowanej populacji nornicy stwierdzono mniejszą niż na powierzchni izolowanej częściowo wartość współczynnika turn-over oraz większy udział osobników młodocianych wśród przybywających do populacji (Tabela 2). Dane te świadczą o większej migracyjności populacji częściowo izolowanej. Osobniki izolowanej populacji nornicy odznaczały się mniejszymi areałami (Tábela 3) oraz mniejszymi przesunięciami areałów między sezonami niż osobniki populacji izolowanej częściowo. Areały osobników populacji izolowanej nakładały się na siebie $w$ większym stopniu niż osobników populacji izolowanej częściowo (Tabela 4). W populacji izolowanej silniej niż w populacji izolowanej częściowo zaznacza się różnica łowności osobników nowoznakowanych i znakowanych uprzednio (Ryc. 4). Swiadczy to o „silniejszym wyrażeniu” organizacji socjalnej populacji izolowanej w porównaniu z populacją izolowaną częściowo. 